\title{
PECTIN DEGRADATION IN RIPENING AND WOUNDED FRUITS
}

\author{
DONALD J. HUBER*, YASAR KARAKURT, JIWON JEONG
}

\begin{abstract}
Horticultural Sciences Department, PO Box 110690, Fifield Hall, University of Florida, Gainesville, FL 32611-0690 USA
\end{abstract}

\begin{abstract}
Pectin depolymerization during fruit ripening has been shown to be largely due to pectinolytic enzymes, including polygalacturonases (E.C. 3.2.1.15) and pectinmethylesterases (E.C. 3.2.1.11). Studies have shown that these enzymes are not the primary determinants of softening, although participation in texture changes during the late stages of ripening seems evident. Pectin depolymerization differs significantly between various fruit types, notably avocado and tomato, even though levels of extractable PG activity in these fruits are similar. Collective evidence indicates that the activities of some cell wall enzymes are restricted in vivo, with maximum hydrolytic potential expressed only in response to tissue disruption or wounding. In contrast, other enzymes reported to participate in pectin degradation, notably $\beta$-galactosidases/exo-galactanases, exhibit in vitro activity far below that anticipated to be required for the loss of cell wall galactosyl residues during ripening. Factors controlling in vivo hydrolysis have not been fully explored but might include apoplastic $\mathrm{pH}$, cell wall inorganic ion levels, non-enzymic proteins including the noncatalytic $\beta$-subunit and expansins, wall porosity, and steric hindrances. Recent studies of cell wall metabolism during ripening have demonstrated an orderly process involving, in the early stages, cell wall relaxation and hemicellulose degradation followed, in the later stages, by pectin depolymerization. A limited number of studies have indicated that radical oxygen species generated either enzymically or non-enzymically might participate in scission of pectins and other polysaccharides during ripening and other developmental processes. Similar mechanisms might also occur in response to wounding, an event typically followed by an oxidative burst. Cell wall degradation as influenced by physical wounding could be of particular relevance to the deterioration of lightly processed fruits.
\end{abstract}

ADDITIONAL INDEX TERMS: apoplast, lipids, membranes, oligogalacturonides, pectin fragments, polygalacturonase, radical oxygen species.

\section{DEGRADAÇÃO DE PECTINA DURANTE O AMADURECIMENTO E EM FRUTOS INJURIDADOS}

RESUMO - A despolimerização de pectina durante o amadurecimento de frutos tem sido apresentada como ação das enzimas pectinolíticas, incluindo polygalacturonases (EC 3.2.1.15) e pectinamethylesterases (EC 3.2.2.22). Estudos tem mostrado que essas enzimas não são as causadoras primárias do amolecimento , no entanto, sua participação nas mudanças da textura durante os estádios finais do amolecimento parecem evidente. A despolimerização difere significativamente entre vários tipos de frutos, notadamente abacate e tomate, mesmo que níveis de atividade de PG nesses frutos sejam similares. Evidências coletivas indicam que as atividades de algumas enzimas de parede celular são restritas in vivo, com o máximo de potencial hidrolítico expresso apenas em resposta ao rompimento do tecido ou ferimentos. Em contraste, outras enzimas participam da degradação de pectina, notadamente $\beta$. galactosidase/exo-galactamases, que exibem in vitro atividades bem abaixo do valor mínimo para a

* corresponding author: gjh@mail.ifas.ufl.edu 
perda de resíduos de galactosyl da parede celular durante o amadurecimento. Fatores que controlam a hidrólise in vivo não tem sido totalmente estudados mas podem incluir o $\mathrm{pH}$ apoplástico, níveis de íons inorgânicos na parede celular, proteínas não enzimáticas, incluindo a $\beta$-subunidade não catalítica e expansina, porosidade da parede e impedimento estérico. Estudos recentes sobre o metabolismo de parede celular durante o amadurecimento tem mostrado ser um processo ordenado, envolvendo nos estádios iniciais, relaxamento da parede celular e degradação de hemicelulose seguida, nos estádios finais, pela despolimerização da pectina. Um limitado número de estudos tem indicado que espécies que geram radicais de oxigênio por meios enzimáticos ou não enzimáticos podem participar da excisão de pectinas e outros polissacarídeos durante o amadurecimento e outros processos de desenvolvimento. Mecanismos similares podem também ocorrer em resposta a ferimentos, um evento tipicamente seguido por um incremento em vias oxidativas. A degradação da parede celular como aquela oriunda do ferimento físico poderá ter particular relevância para a deterioração de frutos ligeiramente processados.

TERMOS ADICIONAIS PARA INDEXAÇÃO: Apoplasto, lipídeo, membranas, oligogalacturonídeos, fragmentos, de pectina, polygalacturonase, espécies com radical de oxigênio.

\section{INTRODUCTION}

The process of ripening, a form of programmed organ death, continues to attract the attention of many researchers. Our understanding of the biology of ripening has been aided considerably by the development and application of molecular biological approaches. Perhaps the most widely studied aspects of ripening include ethylene biosynthesis and signal transduction (Bleecker and Kende, 2000), and softening (Brownleader et al., 1999; Wakabayashi, 2000). Whereas specific cell wall changes contributing to softening remain unknown, it is increasingly evident that the process is complex and involves the sequential, orderly participation of a number of cell wall components, including structural polysaccharides, and enzymic and non-enzymic proteins (Rose et al., 1998; Brummel et al., 1999). The objective of this report is to address the mechanisms and control of pectic depolymerization in fruits during ripening and in response to mechanical wounding.

\section{PECTIN SOLUBILITY DURING RIPENING}

Increased solubility of pectic polysaccharides is one of the most universal features of ripening fleshy fruits. The mechanisms contributing to this process have not been fully elucidated, though the magnitude of solubility increases varies greatly among different fruits. Water-soluble pectins range from $10 \%$ of total cell wall uronic acid content in ripe grapefruit (Hwang et al., 1990) to 35 to $40 \%$ in ripe cherries (FilsLycaon and Buret, 1990) and strawberries (Goto et al., 1996), to as high as $85 \%$ in ripe avocados (Wakabayashi et al., 2000). As noted, the processes contributing to the increases in pectin solubility during ripening are not clear. Transgenic tomato fruit with reduced levels of polygalacturonase (PG) showed a significant reduction in the quantity of water-soluble pectins compared with untransformed fruit (Carrington et al., 1993). Initial increases in pectin solubility in the rapidripening Charentais melon were associated with a loss in pectin-associated galactose, prior to the appearance of PG (Rose et al., 1998). Redgwell et al. (1992) concluded that the initial solubilization of pectins in ripening kiwifruit required neither depolymerization (PG) nor degalactosylation. The low levels or absence of PG in some fruits, including strawberry and grape, support the view that the enzyme is not a ubiquitous requirement for pectin solubilization. The expression of a putative ripening-related pectate lyase gene in strawberry fruit (Medina-Escobar et al., 1997) raises the 
possibility that other, as yet uncharacterized enzymes, are involved in pectin solubility changes. Still other mechanisms may be responsible for pectin solubilization in fruits displaying doublesigmoidal growth kinetics in which ripening and softening occur concomitantly with resumption of rapid cell expansion (Davies and Robinson, 2000).

The levels of pectins soluble in solutions containing chelators, often termed 'ionically bound' pectins, also vary considerably between different fruits. Interpretation of the changes in this pectin fraction is difficult, however, since the solubilization of these polymers is dependent on the removal of calcium. The use of calcium chelators may negate the prior influence of enzymes or other factors on the solubility of these pectins in vivo. Pectin solubility is also influenced by cell wall-isolation protocol (Huber, 1991).

\section{CELL WALL HYDROLASES AND PECTIN DEGRADATION}

Evidence from a number of labs has shown that reducing pectin depolymerization via molecular silencing of PG (Smith et al., 1990; Giovannoni et al., 1989) has little influence on tomato fruit softening until the late stages of ripening (Kramer et al. 1992; Carrington et al., 1993). Consistent with these observations, pectin depolymerization during tomato ripening is restricted compared with in vitro potential (Seymour et al., 1987; Huber and O'Donoghue, 1993; Brummel and Labavitch, 1997). Indeed, accelerated degradation of tomato fruit pectins upon tissue disruption was noted over 60 years ago by Kertesz (1938), who observed a rapid (5 to 10 minutes) change in viscosity of cold-pressed tomato fruit that he attributed to the action of 'pectinase' enzymes. Since the studies of Kertesz and others, the participation of specific pectinases, notably PG and PME, in the rheological properties of tomato fruit juice and paste products has been demonstrated (Tucker et al., 1999). Mol mass distributions of pectins derived from mature-green and ripe tomato fruit, and from intact versus homogenates of ripe tomato fruit are shown in Figures 1 and 2, respectively. The mol mass downshifts in pectins from homogenates (Fig. 2) resulted from holding a freshly homogenized ripe tomato for 5 minutes at room temperature prior to sample processing. As with pectin release from enzymically active cell walls incubated under conditions optimized for PG activity (Huber and Lee, 1988), the low mol mass products recovered from homogenates included low DP (degree of polymerization) pectin fragments.

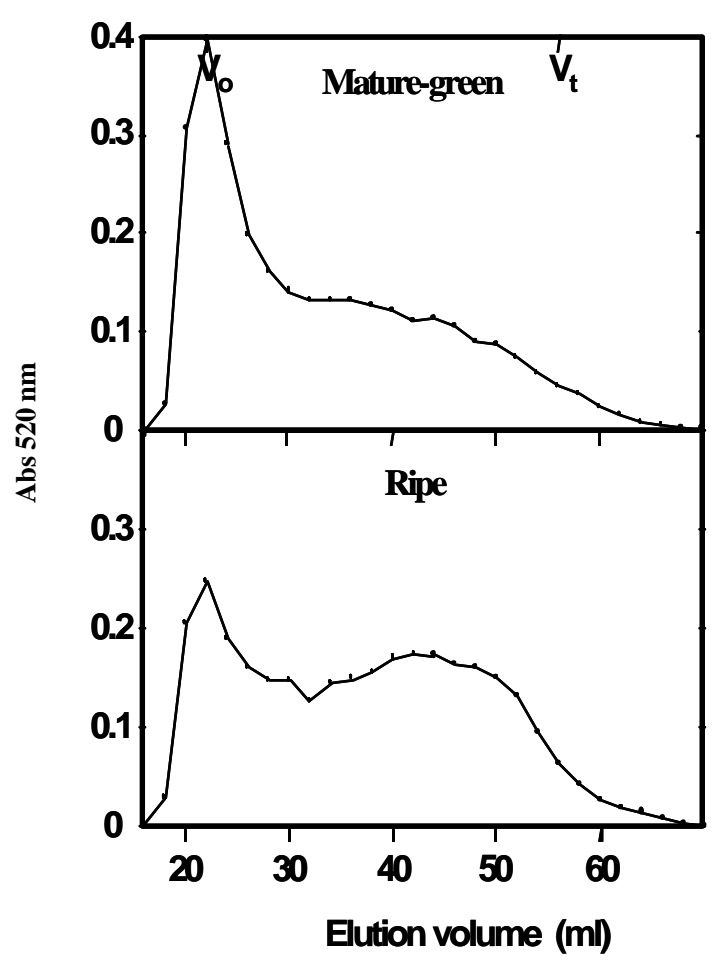

FIGURE 1 - Mol mass distribution of pectins from mature-green (A) and ripe (B) tomato fruit. Combined water-and chelator-soluble pectins $(0.5 \mathrm{mg}$ galacturonic acid equivalents) were applied to a Sepharose CL-4B column (29 cm length, $1.5 \mathrm{~cm}$ diameter) operated with a mobile phase of $200 \mathrm{mM}$ ammonia acetate, $\mathrm{pH} 5.0$. Fractions of $2 \mathrm{ml}$ were analyzed for uronic acids. $\mathrm{V}_{\mathrm{o}}=$ Void volume; $\mathrm{V}_{\mathrm{T}}=$ Total Volume 


\section{REGULATION OF PECTIN DEPOLYMERIZATION IN RIPENING TOMATO FRUIT}

Factors reponsible for restricted $\mathrm{PG}$ action in vivo are not well understood. Almeida and Huber (1999) observed that the $\mathrm{pH}$ of pressure-exuded apoplastic fluid was over 6.0 in mature-green tomato fruit, declining to 4.5 during ripening (Fig. 3). Similar changes in apoplastic $\mathrm{pH}$ were reported for ripening peach and nectarine fruits (Ugalde et al. 1988). Tomato PG in vitro is catalytically inactive at pH 6.0 (Themmen et al., 1982), the $\mathrm{pH}$ of mature-green fruit apoplast, whereas the $\mathrm{pH}$ of ripe fruit apoplast is similar to the in vitro optimum for the enzyme. The influence of apoplastic $\mathrm{pH}$ and mineral levels in the regulation of cell wall metabolism is well recognized for other plant systems (Cosgrove,

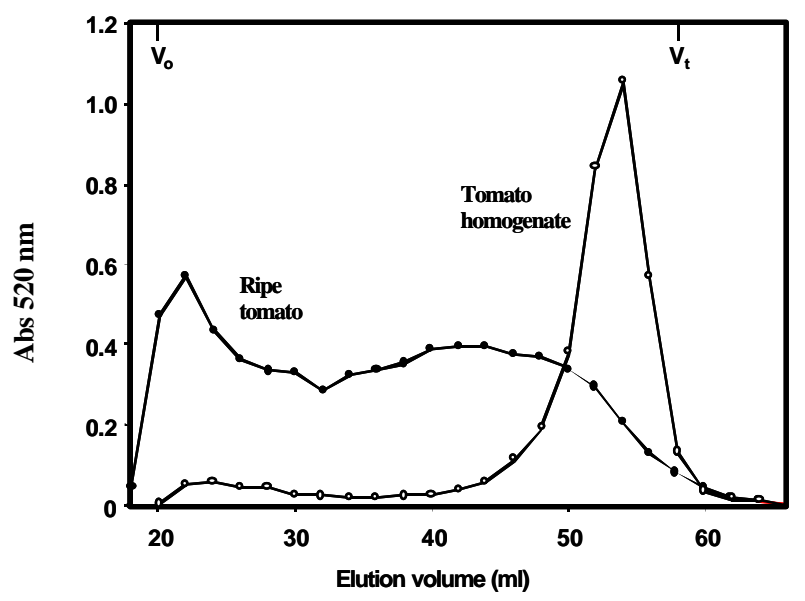

FIGURE 2 - Mol mass distribution of pectins from intact ripe tomato fruit and ripe tomato homogenates. Intact fruit were processed in phenolic solvents to inactivate enzymes and subsequently used for pectin extraction (Huber 1991). Other fruit were homogenized in buffer (50 mM Na-acetate, $\mathrm{pH} 4.5$ ) and the homogenate permitted to stand at room temperature for 5 minutes. Afterward, the homogenate was processed as for intact fruit. Pectins from the intact and homogenized fruit were applied to a Sepharose 4B-200 column as described for Figure 1.
1999; 2000; Sakurai, 1998; Soga et al., 2000) but has received little attention in fruit tissues. A survey of a number of fruit cell wall enzymes including xyloglucanases (XGase), xyloglucan endotransglycosylase(XET),endo-\&- 1,4glucanases $\left(\mathrm{C}_{\mathrm{x}}\right.$-cellulases $), \beta$-galactosidases and other glycosidases, and pectin-hydrolyzing enzymes reveals $\mathrm{pH}$ optima ranging from 4.0 to 7.0 (Almeida, 1999). Although these represent values determined from assays performed in vitro, often with non-native substrates and in buffers selected to optimize activity, they offer evidence that dynamic changes in apoplast $\mathrm{pH}$ during ripening could strongly influence the sequence and progression of wall disassembly. The expression of aberrant textural conditions in fruits exposed to irradiation (Paull, 1996; Yu et al., 1996; Kovacs et al., 1997), high or low temperatures (Sozzi et al., 1996; Jackman et al., 1982; Fernandez-Trujillo et al., 1998; Bauchot et al., 1999), and the occurrence of other textural disorders including mealiness in nectarines (von Mollendorff et al., 1993) and ethylene-induced watersoaking in watermelon fruit (Elkashif and Huber, 1988) might reflect, in part, altered apoplastic conditions ( $\mathrm{pH}$, ion balance) brought about either actively or passively by stress-induced membrane dysfunction.

The trend of decreasing apoplastic $\mathrm{pH}$ (and increasing $\left[\mathrm{K}^{+}\right]$, Almeida and Huber, 1999) during tomato ripening would be expected to enhance PG activity; however, pectin depolymerization patterns indicate that the activity of the enzyme in healthy, ripe fruit remains well below in vitro catalytic potential (Seymour et al., 1987; Huber and O'Donoghue, 1993; Brummel and Labavitch, 1997). The high levels of calcium in tomato fruit apoplast might contribute to the persistent inhibition of pectin hydrolysis during ripening. Calcium levels in apoplastic liquid from tomato fruit remain nearly constant (approximately $4 \mathrm{mM}$ ) throughout ripening (Almeida and Huber, 1999), and are more than adequate to strongly suppress PG-mediated pectin release from isolated cell walls (Rushing and Huber, 1987). Additional evidence for regulation of PG by apoplastic 
conditions was the observation that incubation of purified tomato PG 2 with cell walls in solutions mimiking the $\mathrm{pH}$ and ionic composition of apoplastic fluid of ripe fruit greatly reduced pectin depolymerization compared with that occurring in cell walls incubated at $\mathrm{pH} 4.5$ without added ions (Almeida and Huber, unpublished).

\section{PECTIN DEPOLYMERIZATION IN RIPENING AVOCADO FRUIT}

The pattern of pectin depolymerization in ripening avocado fruit (Huber and O'Donoghue, 1993) provides a sharp contrast to that noted for tomato and other fruits including apple (Fischer et al., 1994), kiwifruit (Gallego and Zarra, 1997; Soda et al., 1987), Japanese and Chinese pear (Moriguchi et al., 1998), plum (Boothby, 1983), carambola (Chin et al., 1999), and papaya (Paull et al., 1999). Nectarine (Lurie et al., 1994) and mango (Muda et al., 1995) fruits exhibit more extensive hydrolysis than the above examples, yet the mol mass downshifts do not involve a large proportion of cell wall pectins as is evident for avocado. As illustrated in Figure 4, water-soluble pectins from avocado undergo marked mol mass downshifts during ripening, eluting as a symmetrical peak near the $V_{t}$ (total column volume). Sakurai and Nevins (1997) reported a similar trend for pectin mol mass downshifts during avocado ripening. As evident from Figure 4 , the mol mass distribution of pectins from ripe avocado was quite similar to that of pectins from tomato homogenates (Fig. 2). Wakabayashi et al. (2000) have shown that the extensive hydrolysis of avocado pectins requires the prior or concerted action of PME. In addition to the mol mass downshifts, nearly 85 to $90 \%$ of the total uronic acid in cell walls from ripe avocado fruit were recovered from cell wall isolates extracted in water. We are aware of no other fruit in which such large quantities of pectins are readily solubilized from cell wall isolates (ethanol- insoluble solids) under mild, nondestructive conditions.

The biochemical basis for the comparatively extensive hydrolysis of pectins during ripening of avocado compared with tomato fruits is not clear. The presence of only low mol mass PG (46 and $48 \mathrm{kD}$ ) isoforms in avocado (Wakabayashi and Huber, 2001) compared with the low (45 to $46 \mathrm{kD}$ ) and high mol mass ( 100 $\mathrm{kD}$ PG1, a heterodimer of PG2 plus the \&subunit protein) isoforms in tomato suggests that \&-subunit-type proteins may be absent or less influential in avocado fruit. As discussed by DellaPenna et al. (1996), the $\beta$-subunit, a novel, aromatic amino acid-rich glycoprotein first characterized in tomato fruit, may function to tether PG isozyme 2 to strategic sites in the cell wall, limiting enzyme mobility. The molecular silencing of the $\beta$-subunit protein in tomato fruit (Watson et al., 1994), however, was more influential at increasing pectin solubility rather than the extent of depolymerization (Watson et al., 1994; Chun and Huber, 2000). Although interaction of the \&-subunit protein and PG in vivo has been questioned (Pressey, 1988; Moore and Bennett, 1994), tomato fruit expressing a $\beta$-subunitantisense gene (Watson et al., 1994) are significantly softer when ripe than wild-type fruit (Chun and Huber, 2000).

Another notable distinction between the tomato and avocado PGs is the considerably higher $\mathrm{pH}$ optima (6.0) for the avocado (Wakabayashi and Huber, 2001) compared with the tomato (3.5 to 4.5) isoforms (Pressey and Avant, 1973). Although the $\mathrm{pH}$ of avocado fruit apoplast is not known, a high $\mathrm{pH}$ would favor the activity of not only PG, but also PMEs, many of which possess relatively high $\mathrm{pH}$ optima (5 to 7). Additional diversity in fruit endo-PGs was evident from studies of banana (Pathak and Sanwal, 1998; Pathak et al., 2000), shown to contain 2 isoforms with $\mathrm{pH}$ optima of 3.3 and 4.3. As in tomato, one of the isoforms 
from banana is of high mol mass $(130 \mathrm{kD})$ and heat stable. In contrast to tomato PGs (Ali and Brady, 1982), the banana (Pathak et al., 2000) and avocado (Wakabayashi and Huber, 2001) isoforms are strongly inhibited by mercury, indicating a requirement for sulfhydryl groups.

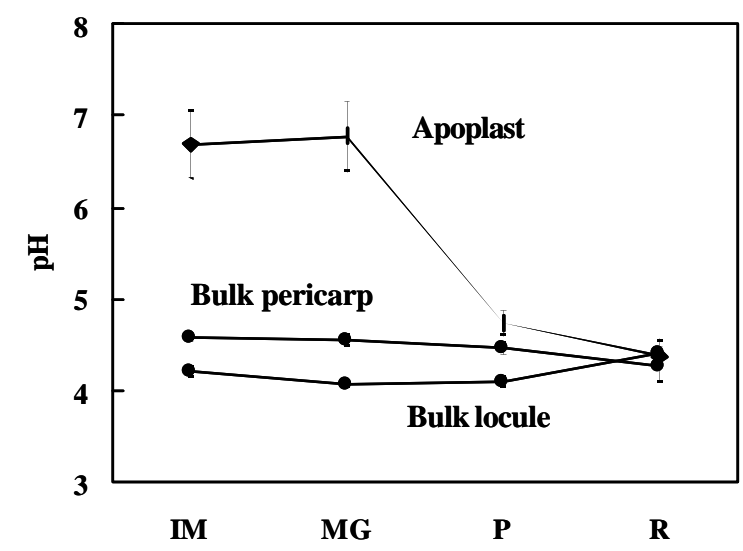

FIGURE 3 - $\mathrm{pH}$ of the apoplastic and bulk pericarp and locule tissues at different maturity stages. I, immature; MG, mature-green; $\mathrm{P}$, pink; R, ripe. Error bars represent SE of six observations. (Almeida and Huber 1999) Used with permission.

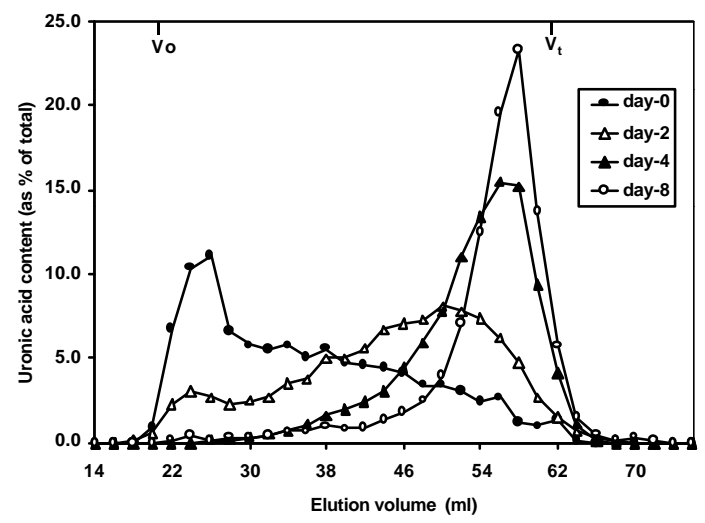

FIGURE 4 - Mol mass distribution of water-soluble pectins from 'Hass' avocado fruit during ripening. Details as described for Figure 1. 0 days, fruit at harvest and after 2, 4, 6, and 8 days (full-ripe, average firmness $10 \mathrm{~N}$ ) storage at $25^{\circ} \mathrm{C}$.

\section{AVOCADO PECTIN DEPOLYMERIZATION AND FRUIT SOFTENING}

The extensive hydrolysis of pectins in ripening avocado relative to tomato fruits raised the question as to whether PG might be more influential in the softening of avocado. In an effort to suppress the accumulation of PG in avocado, fruit were treated following harvest with 1-MCP (1-methylcyclopropene), a potent inhibitor of ethylene action (Sisler and Serek, 1997; 1999). As shown in Figure 5 A, the firmness of control (no 1MCP) fruit declined from nearly $250 \mathrm{~N}$ at harvest to about $10 \mathrm{~N}$ over a 2 -week period at $13{ }^{\circ} \mathrm{C}$. Fruit treated with $0.9 \mu 11^{-1} 1-\mathrm{MCP}$ required nearly 4 weeks to reach firmness values of $10 \mathrm{~N}$. PG levels were significantly affected by $1-\mathrm{MCP}$ treatment (Figure $5 \mathrm{~B}$ ), remaining at harvest levels for up to

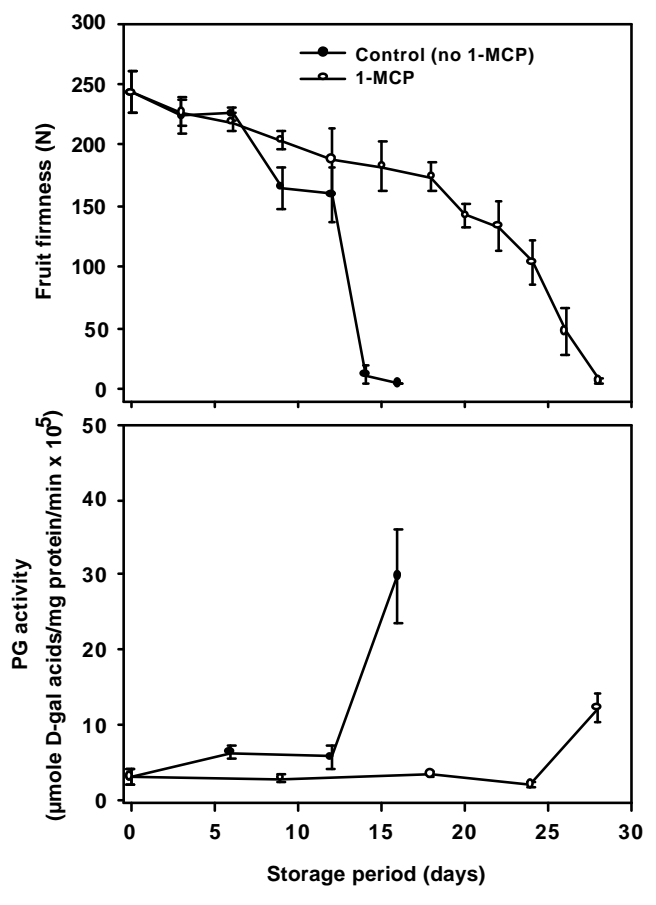

FIGURE 5 - Fruit firmness (A) and PG activity (B) of 'Booth 7' avocados treated with 1-MCP $\left(0.9 \mu 11^{1}\right.$ for $12 \mathrm{~h}$ at $20{ }^{\circ} \mathrm{C}$ ) and then stored at $13{ }^{\circ} \mathrm{C}$. Vertical bars represent standard deviation. (Jeong and Huber, unpublished.) 
25 days. During this period, the firmness of 1MCP-treated fruit declined from $250 \mathrm{~N}$ to $100 \mathrm{~N}$. In both control and 1-MCP-treated fruit, PG accumulation was temporally correlated with the final trend of softening, during which time firmness decreased to $10 \mathrm{~N}$. These data indicate that significant changes in avocado firmness do occur in the absence of appreciable PG activity, and that the accumulation of the enzyme parallels the decline in firmness occurring during the late stages of ripening. These observations are consistent with interpretations of the role of PG in tomato fruit softening (Kramer et al., 1992; Carrington et al., 1993). The influence of reduced PG levels on pectin solubility and depolymerization patterns in 1-MCP-treated avocado fruit is currently under investigation.

\section{PRODUCTION OF PECTIC FRAGMENTS DURING FRUIT RIPENING}

In spite of the extensive hydrolysis of pectins occurring in ripening avocado, low-DP oligomers $(<10)$ are minor reaction products (Huber and O'Donoghue, 1993). Since PGs from avocado (and tomato) are capable of producing low-DP products, including monomer and dimer, from homogalacturonan (eg. polygalacturonic acid) substrates (Patel and Phaff, 1960; Reymond and Phaff, 1965), the generation of only trace levels of endogenous oligomers during ripening suggests that structural properties of the products impart resistance to exhaustive hydrolysis. The neutral sugar/galacturonic acid mol ratio of the low mol mass, water-soluble pectins in ripe fruit was nearly 1.0 (Jeong and Huber unpublished). This indicates that high glycosylation, as well as methylesterification, which persists at $20 \%$ in ripe fruit (Wakabayashi et al., 2000), may be involved in the arrest of hydrolysis. We have also noted a lack of endogenous, low-DP-oligomer production in ripe tomato fruit (Huber and O'Donoghue, 1993). In contrast, Melloto et al. (1994) and Dumville and Fry (2000) reported the presence of low-DP oligouronides in tomato fruit. The latter report expressed the view that oligouronides were not typically produced in healthy plant tissues, with the notable exception of tomato fruit. In our experience, however, tomato fruit do not appear to represent an exception. Excised (wounded) tomato pericarp discs incubated in buffer at $23^{\circ} \mathrm{C}$ released significant quantities of pectic oligomers, and this release was proportional to cut surface area (Huber and Lee 1989). Discs maintained in buffer at $1^{\circ} \mathrm{C}$ released only trace levels of pectins, most of which were of high mol mass. This indicates that endogenous oligouronides were not present at quantitatively significant levels prior to wounding.

\section{GALACTANASES AND PECTIN DEGRADATION}

In addition to endo-PGs, other enzymes have been reported to depolymerize or otherwise influence the mol mass distribution of pectins in fruits. Among these enzymes, most attention has focused on \&-galactosidases (EC 3.2.1.23), largely because galactosyl residues represent the major cell wall neutral sugar lost during ripening of most fruits (Gross and Sams, 1984). $\beta$-Galactosidases from fruit and other sources are similar in showing high activity toward $\Delta$ - $\mathrm{NO}_{2}$-phenyl \&-Dgalactopyranoside, and $\beta$-galactosidases (and other glycosidases) have been reported in all fruits examined. In only a few studies, however, have \&galactosidases, which are typically present in multiple isoforms (Pressey, 1983; Carey et al., 1995; Smith and Gross, 2000; Li et al., 2001), been shown to degrade isolated cell walls or polysaccharides. The cell wall-active isoforms likely represent exo- $\beta$-D-galactanases rather than oligomer- or dimer-preferring glycosidases. Of three \&-galactosidases reported in tomato fruit, only one isoform $\beta$-gal II), the levels of which increased 4-fold during ripening, degraded pecticderived substrates (Pressey, 1983). More refined analysis of tomato $\beta$-gal II (Carey et al. 1995) confirmed the galactan-hydrolyzing activity of the enzyme; however, the purified enzyme exhibited unusual behavior in being active toward isolated cell walls but not purified tomato galactan. Based 
on the capacity of the enzyme to release only monomeric galactose from galactan substrates, the authors identified the enzyme as an exo-1,4- $\beta$-Dgalactanase. A $\beta$-galactosidase from kiwifruit (Ross et al., 1993) also produced monomeric galactose from a number of substrates, including a pectic fraction; however, the levels of galactose released were considerably lower than the decline in cell wall galactosyl residues during ripening. Extremely low activity toward cell walls or galactan polymers was also evident for $\beta$ galactosidases from apple (Ross et al., 1994) and Japanese pear (Kitagawa et al., 1995) fruits. Ross et al. (1993) has stated that if the galactanhydrolyzing $\beta$-galactosidases are solely responsible for the decline in cell wall galactosyl residues during ripening, then the activity of the enzymes must be considerably higher in vivo.

The effect of degalactosylation on the physical properties of pectins is not known. $\beta$ Galactosidases/exo-galactanases from avocado (de Veau et al., 1993) and muskmelon (Ranwala et al., 1992) fruits were shown to induce mol mass downshifts in isolated pectin fractions, presumably via hydrolysis of pectic galactans. In the latter study, treatment of an EDTA-soluble pectin with a high-saline extractable \&-galactosidase resulted in mol mass downshifts far in excess of those noted during muskmelon ripening. Scrutiny of the gel filtration profiles, however, reveals no evidence for monomers, the expected product of $\beta$ galactosidase/exo-galactanase action (Carey et al., 1995; Ross et al., 1993). Since the enzymes used by Ranwala et al. (1992) were only partially purified, the participation of enzymes other than \&-galactosidases in the pectin mol mass downshifts in ripening muskmelon fruit cannot be discounted. In support of this view, Hadfield et al. (1998) reported that expression of melon cDNA clones with high homology to PG clones from other fruits coincided with the onset of pectin mol mass downshifts and with the accumulation of pectin-degrading activity.

A recent analysis of tomato $\beta$ galactosidases has revealed a minimum of seven \&-galactosidase genes (Smith and Gross, 2000), 6 of which were suggested to participate in the deglycosylation of tomato cell wall polysaccharides. Moreover, as noted by these authors, differences in expression patterns during fruit development and the reported differences in substrate specificities of $\beta$-galactosidases/exogalactanases ( $\mathrm{Li}$ et al., 2001) raise the possibility that these enzymes target different substrates and function in a variety of developmental processes. The loss in cell wall galactosyl residues in senescing carnation petals (de Vetten and Huber, 1990) and in harvested asparagus spears (O’Donoghue et al., 1998; Rodríguez et al., 1998), attests to multiple functions for galactanases and galactose turnover. In addition to their effects on pectic polymers, some $\beta$-galactosidases are active toward hemicelluloses (Ranwala et al., 1992; Li et al., 2001), resulting in the production of monomeric galactose (Li et al., 2001). That galactosidases and galactanases might play a role in textural properties is supported by a recent report that pea cotyledons containing galactan-rich pectin were significantly firmer than pecticgalactan-depleted cotyledons (McCartney et al., 2000). Tucker et al. (1999) reported that coldbreak tomato pastes from fruit expressing a galactanase antisense-gene exhibited higher viscosity compared with pastes from normal fruit, providing indirect evidence for a role for these enzymes in pectin degradation.

\section{NONHYDROLYTIC MECHANISMS CONTRIBUTING TO PECTIN DEPOLYMERIZATION IN RIPENING FRUITS}

Reports of expansin-type proteins in a range of vegetative organs including leaves, coleoptiles, hypocotyls and others (Cosgrove, 1999; 2001) have demonstrated a role for these 'nonhydrolytic' proteins in extension growth. Recent studies have shown that structurally related proteins may play important roles in fruit growth and softening, either via direct effects on specific cell wall polymers, promoting cell wall relaxation or creep, or indirectly by increasing the 
accessibility of wall polysaccharides to enzymic hydrolysis (Brummel et al., 1999; Rose et al., 2000). Ripening-related, expansin-type activity has been reported in tomato, pepper, avocado and pear (Rose et al., 2000), strawberry (Civello et al., 1999), and peach (Hayama et al., 2000) fruits. Evidence for a role of expansins in softening was observed in studies of tomato fruit with suppressed or over-expressed levels of Expl, a ripeningspecific expansin (Brummel et al., 1999). Fruit under-expressing Exp1 protein were firmer than controls, exhibited suppressed pectin depolymerization during late ripening, but showed normal mol mass downshifts in hemicelluloses. Fruit over-expressing Exp1 were softer throughout ripening, and exhibited unaltered pectin metabolism but enhanced breakdown of hemicelluloses. Creep activity, assessed from the addition to cucumber hypocotyls of cell wall protein extracts, demonstrated expansin-like proteins in a variety of fruits, though the abundance or activity differed significantly (Rose et al., 2000). In one contrasting report, Hayama et al. (2000) observed no differences in transcript abundance or immunologically detected levels of a ripening-specific expansin between melting-flesh and stony-hard peach cultivars. Based on models of the function of expansin, however, only one component (creep) is mediated via direct action of the protein. This effect may not be evident in firmness determined via puncture analysis of peach mesocarp. Other, indirect effects of expansins, including enhanced susceptibility of cell wall polymers to enzyme hydrolysis, would depend not only on expansin levels per se but also on the levels and activities of hydrolytic enzymes. Consequently, that expansin levels are similar between the two peach cultivars does not preclude a role for the protein in softening.

An interesting though not widely examined mechanism of polysaccharide depolymerization in ripening fruit envisions the participation of radical oxygen species (ROS). The first report of the potential involvement of ROS in the degradation of cell wall polysaccharides under physiological conditions appears to be that of
Miller (1986), who observed a decrease in viscosity and generation of reducing sugars upon incubation of cell wall polymers, including pectin and polygalacturonic acid, in $1 \mathrm{mM} \mathrm{H}_{2} \mathrm{O}_{2}$ at $\mathrm{pH}$ 6.5. $\mathrm{H}_{2} \mathrm{O}_{2}$-mediated degradation was also noted with tomato and cucumber fruit cell walls. Fry (1998) observed more extensive hydrolysis of pectin, xyloglucan, and other polysaccharides by including ascorbate and $\mathrm{Cu}^{2+}$, both known components of apoplastic fluid, along with $\mathrm{H}_{2} \mathrm{O}_{2}$. By examining the effects of free radical scavengers, Fry (1998) concluded that the hydroxyl radical $(\cdot \mathrm{OH})$, generated from a Fentontype reaction, was responsible. The presence in the apoplast of components required for $\cdot \mathrm{OH}$ generation (Takahama and Oniki, 1997; Zarra et al., 1999) and the rapid occurrence of radicalmediated polymer scission under physiological $\mathrm{pH}$ values led Fry (1998) and Schweikert et al. (2000) to conclude that radical-mediated polysaccharide degradation may be relevant in many developmental processes including germination, growth, and ripening. Whereas Miller (1986) and Fry (1998) emphasized a role for ROS generated via non-enzymic reactions, Schweikert et al. (2000) considered the participation of $\cdot \mathrm{OH}$ produced through peroxidase-mediated reactions. Since many forms of peroxidase are tightly wall-associated (Sato et al., 1995; Nair and Showalter, 1996), peroxidase- versus nonenzymic-generated radicals would seem to afford more control over polysaccharide scission by facilitating targeted or site-directed cleavage. While ROS-mediated scission of cell wall polysaccharides offers an interesting adjunct to enzyme-based (hydrolases) or 'creep' (expansins) mechanisms, the apoplast is well endowed with antioxidant enzymes (eg. catalase, reductases) and metabolites (Vanacker et al., 1998) whose effects would tend to reduce the occurrence of radical-mediated degradation. It is possible that the competence of the antioxidant system becomes compromised during ripening and senescence (Bartosz, 1997; Kanazawa et al., 2000), progressively shifting the balance in favor of prooxidative reactions. 


\section{POLYSACCHARIDE DEGRADATION IN LIGHTLY PROCESSED FRUITS}

If radical-based mechanisms of polysaccharide scission are more operational in wounded or otherwise physically compromised tissues (Bolwell et al., 1995), then they may be of importance in the deterioration of lightly processed (LP) fruits. Fruits destined for processing as LP products are nearly fully ripe and are subjected to a combination of peeling, cutting, slicing, or dicing. Studies have shown that accelerated softening is a prominent feature of LP fruits (O'Connor-Shaw et al., 1994; Watada and Qi, 1999). Since LP fruits are typically held at $\# 5^{\circ} \mathrm{C}$, low-temperature injury may contribute to the decline in tissue firmness (Jackman et al., 1992), particularly in fruits of tropical origin. Studies of LP fruits, however, typically do not include intact fruit stored under identical conditions, so it is difficult to ascertain the influence of wounding versus low temperature in enhancing firmness decline. As shown in Figure 6, the firmness of LP papaya fruit declined significantly more rapidly and extensively than tissue derived from intact fruit stored under identical conditions, supporting the view that the accelerated softening of LP papaya fruit is not a reflection of low-temperature injury.

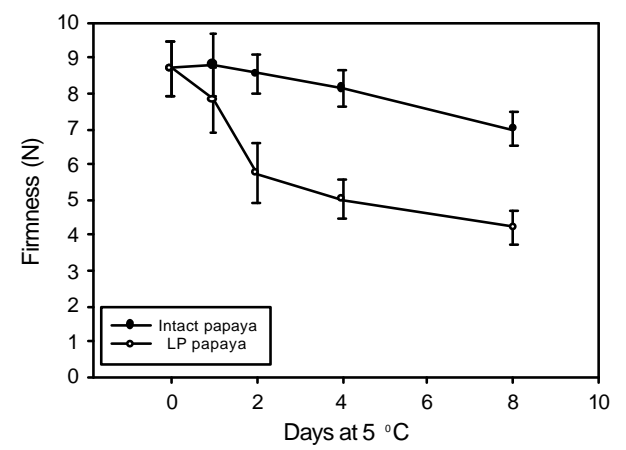

FIGURE 6 - Firmness of intact and lightly processed (LP) papaya fruit during storage at $5{ }^{0} \mathrm{C}$. (Karakurt and Huber, unpublished).

Although there is limited information on the mechanism of deterioration of LP fruits stored at low temperatures, studies of physically wounded

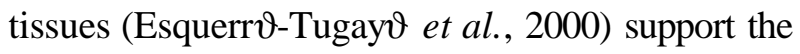
notion that a multitude of processes, including polysaccharide degradation, are involved. As noted above, pectic oligomers released from wounded tomato pericarp (Huber and Lee, 1989) are in excess of levels recovered from intact fruit. The increased production of oligouronides may involve alleviation of in vivo constraints on pre-existing PG, or wound-induced enzyme synthesis. Bergey et al. (1999) reported that PG transcript and activity levels increased in tomato leaves in response to mechanical wounding, or to the application of pectic fragments or systemin. The comparable response in both wounded and nonwounded leaves indicates systemic activation. Moretti et al. (1998) found that extractable PG activity increased nearly $30 \%$ in the wounded tissue of impact-bruised tomato fruit. While the latter observation provides evidence for woundinduced PG accumulation in tomato fruit, the rapid depolymerization of pectins in fruit homogenates indicates that activation of pre-existing $P G$ is sufficient to stimulate oligomer production in wounded tomato fruit. Figure 7 illustrates the mol mass distribution of water-soluble pectins from

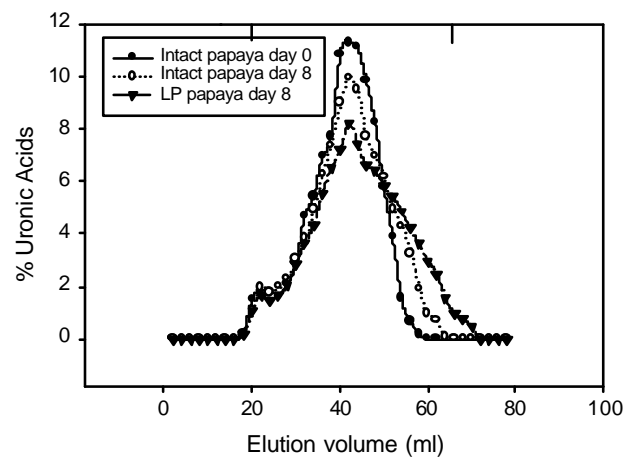

FIGURE 7 - Molecular mass distribution of watersoluble pectins from intact and lightly processed (LP) papaya fruit during storage at $5{ }^{0} \mathrm{C}$. Water-soluble pectins ( $0.5 \mathrm{mg}$ galacturonic acid equivalents) were applied to a CL 4B-200 column as described for Figure 1. (Karakurt and Huber, unpublished). 
intact and wounded (LP) papaya fruit stored for 8 days at $5{ }^{\circ} \mathrm{C}$. Although pectins from both intact and LP fruit changed during storage, those from LP fruit were of greater polydispersity and showed more depolymerization than pectins from intact fruit. Consistent with the mol mass profiles, extractable polygalacturonase activity increased nearly $30 \%$ in the LP compared with intact fruit.

Another prominent feature of LP fruit is increased respiration, with LP fruits typically exhibiting a 2- to 3-fold increase compared with the intact commodity (Watada et al., 1996). In the short-term, it is likely that the pheripheral, injured cells have a proportionally greater contribution to enhanced respiration. The respiratory response to wounding may have mechanistic parallels to the 'oxidative burst,' a response of plant tissues to pathogen ingress involving the production of $\mathrm{H}_{2} \mathrm{O}_{2}$ and ROS (Bolwell et al., 1995; Low and Merida, 1996). As noted above, some authors have proposed that non-enzymically (Miller, 1986; Fry, 1998) and peroxidase- (Schweikert et al., 2000) generated $\mathrm{H}_{2} \mathrm{O}_{2}$ and/or ROS might contribute to the degradation of pectic and other cell wall polysaccharides in fruits. A contribution of lipoxygenase (LOX) activity to $\mathrm{ROS}\left(\mathrm{O}_{2} /{ }^{-}\right)$ production has also been suggested (Lynch and Thompson, 1984). LOX isoforms are widely

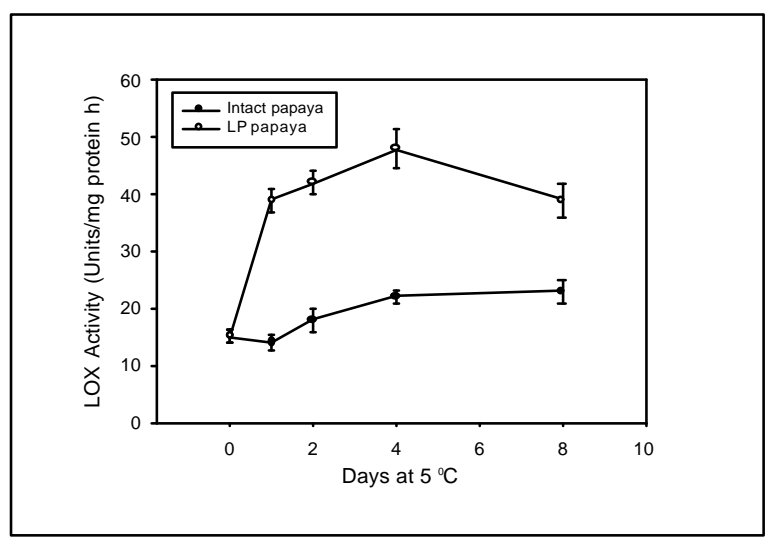

FIGURE 8 - Lipoxygenase activity in intact and lightly processed (LP) papaya fruit during storage at $5{ }^{0} \mathrm{C}$. (Karakurt and Huber, unpublished). distributed in plant tissues, and likely are involved in diverse developmental processes; however, the enzymes are frequently associated with stress and senescence phenomena (Rosahl, 1996). As shown in Figure 8, the total LOX activity of LP papaya fruit increased nearly 2 -fold within 24 hours at $5^{\circ}$ C compared with intact fruit and remained significantly higher throughout 8 days of storage. In addition to the possible contribution of LOX to ROS production and membrane and polysaccharide degradation, peroxidative reactions involving membrane-derived fatty acids would generate signal-transduction metabolites (jasmonic acid, traumatin) and, consequently, activate defense responses systemically.

\section{SUMMARY}

There is likely no one scenario that accurately describes the course of pectin metabolism in ripening fruits. On the one hand, pectin depolymerization is a consistent feature of fruit expressing polygalacturonase, though the extent of hydrolysis varies greatly among different fruits. On the other hand, pectin solubilization is characteristic of all fleshy fruits, indicating that factors other than PG contribute to structural modification of pectins. Endogenous levels of PG and PME do not always correlate well with trends of pectin depolymerization, indicating that the activity of these and likely other enzymes is restricted in vivo. Mechanical wounding appears to alleviate constraints on hydrolysis, resulting in more extensive pectin degradation. Degalactosylation, and deglycosylation in general, may contribute to pectin changes during the early stages of ripening. Radical oxygen species of various origins have been proposed to participate in the degradation of pectins and other polysaccharides during ripening, and may be of special relevance to LP (wounded) fruits.

ACKNOWLEDGMENTS - Journal Series No. R-08257 of the Florida Agricultural Experiment Station. 


\section{REFERENCES}

ALI, Z.M. \& BRADY, C.J. Purification and characterization of the polygalacturonases of tomato fruits. Australian Journal of Plant Physiology, 9,155-169, 1982.

ALMEIDA, D. P. F. \& HUBER, D. J. Apoplastic $\mathrm{pH}$ and inorganic ion levels in tomato fruit: $\mathrm{A}$ potential means for regulation of cell wall metabolism during ripening. PHYSIOLOGIA PLANTARUM, 105: 506-512, 1999.

ALMEIDA, D.P.F. Cell wall metabolism in ripening and chilled tomato fruit as influenced by the $\mathrm{pH}$ and mineral composition of the apoplast. $\mathrm{PhD}$ Dissertation, University of Florida, Gainesville, FL: UMI number 9956544, 1999.

BARTOSZ, G. Oxidative stress in plants. Acta Physiologia Plantarum,19:47-64, 1997.

BAUCHOT, A.D.; HALLET, I.C.; REDGWELL, R.J. \& LALLU, N. Cell wall properties of kiwifruit affected by low temperature breakdown. Postharvest Biology and Technology, 16:245-255, 1999.

BERGEY, D.R.; OROZCO-CARDENAS, M.; DE MOURA, D.S. \& RYAN, C.A. A wound and systemin-inducible polygalacturonase in tomato leaves. Proceedings of the National Academy of Science, 96:1756-1760, 1999.

BLEECKER, A.B. \& KENDE, H. Ethylene: A gaseous signal molecule in plants. Annual Review of Cell Development and Biology, 16:1-18, 2000.

BOOTHBY, D. Pectic substances in developing and ripening plum fruits. Journal of the Science of Food and Agriculture, 34:11171122, 1983.

BOLWELL, G. P.; BUTT, V. S.; DAVIES, D.R. $\&$ ZIMMERLIN, A. The origin of the oxidative burst in plants. Free Radical Research, 23:517-532, 1995.
BROWNLEADER, M. D.; JACKSON, P.; MOBASHERI, A.; PANTELIDES, A. T.; SUMAR, S.; TREVAN, M. \& DEY, P.M. Molecular aspects of cell wall modifications during fruit ripening. Critical Reviews in Food Science and Nutrition, 39:149-164, 1999.

BRUMMELL, D.A.; HARPSTER, M.H.; CIVELLO, P.M.; PALYS, J.M.; BENNETT, A. B. \& DUNSMUIR, P. Modification of expansin protein abundance in tomato fruit alters softening and cell wall polymer metabolism during ripening. The Plant Cell, 11:2203-2216, 1999.

BRUMMELL, D.A. \& LABAVITCH, J.M. Effect of antisense suppression of endopolygalacturonase activity on polyuronide molecular weight in ripening tomato fruit and in fruit homogenates. Plant Physiology, 115: 717-725, 1997.

CAREY, A. T.; HOLT, K.; PICARD S.; WILDE, R.; TUCKER, G. A.; BIRD, C. R.; SCHUCH, W. \& SEYMOUR, G. B. Tomato exo-(1-4)beta-D-galactanase. Isolation, changes during ripening in normal and mutant tomato fruit, and characterization of a related cDNA clone.

Plant Physiology, 8:1099-1107, 1995.

CARRINGTON, C. M. S.; GREVE L. C. \& LABAVITCH J. M. Cell wall metabolism in ripening fruit. VI. Effect of the antisense polygalacturonase gene on cell wall changes accompanying ripening in transgenic tomatoes. Plant Physiology, 103: 429-434, 1993.

CHIN, L-H.; ALI, Z.M. \& LAZAN, H. Cell wall modifications, degrading enzymes and softening of carambola fruit during ripening. Journal of Experimental Botany, 50:767-775, 1999.

CHUN, J.P. \& HUBER, D.J. Firmness, ultrastructure, and polygalacturonase activity in tomato fruit expressing an antisense gene for the $\$$-subunit protein. Journal of Plant Physiology, 157:153-160, 2000. 
CIVELLO, P.M.; POWELL, A.L.T.; SABEHAT, A. \& BENNETT, A.B. An expansin gene expressed in ripening strawberry fruit. Plant Physiology, 121:1273-1279, 1999.

COSGROVE, D.J. Enzymes and other agents that enhance cell wall extensibility. Annual Review of Plant Physiology and Plant Molecular Biology, 50:391-417, 1999.

COSGROVE, D.J. Expansive growth of plant cell walls. Plant Physiology and Biochemistry, 38:109-124, 2000.

DAVIES, C. \& ROBINSON, S.P. Differential screening indicates a dramatic change in mRNA profiles during grape berry ripening. Cloning and characterization of cDNAs encoding putative cell wall and stress response proteins. Plant Physiology, 122:803-812, 2000 .

DE VEAU E.J.; GROSS K.C.; HUBER, D. J. \& WATADA, A. Degradation and solubilization of pectin by beta-galactosidases purified from avocado mesocarp. Physiologia Plantarum 87, 279-285, 1993.

DE VETTEN, N. C. \& HUBER, D. J. Cell wall changes during the expansion and senescence of carnation (Dianthus caryophyllus) petals. Physiologia Plantarum, 78:447-454, 1990.

DELLAPENNA D.; WATSON C.; LIU J. \& Schuchman D. The \&-subunit of tomato fruit polygalacturonase isoenzyme 1 defines a new class of proteins involved in pectin metabolism: AroGPs (Aromatic amino acid rich glycoproteins). Visser J, Voragen AGJ (eds) Pectins and Pectinases, Elsevier Science, Amsterdam, pp 247-262, 1996.

DUMVILLE, J.C. \& FRY, S.C. Uronic-acid oligosaccharins: Their biosynthesis, degradation and signalling roles in nondiseased plant tissues. Plant Physiology and Biochemistry, 38:125-140, 2000.
ELKASHIF, M. \& HUBER, D. J. Electrolyte leakage, firmness, and scanning electron microscopic studies of watermelon fruit treated with ethylene. Journal of the American Society for Horticultural Science, 113:378-381, 1988.

ESQUERRI-TUGAYI, M.T.; BOUDART, G. \& DUMAS, B. Cell wall degrading enzymes, inhibitory proteins, and oligosaccharides participate in the molecular dialogue between plants and pathogens. Plant Physiology and Biochemistry, 38:157-163, 2000.

FERNANDEZ-TRUJILLO, J.; CANO, A., \& ARTES, F. Physiological changes in peaches related to chilling injury and ripening. Postharvest Biology and Technolology, 13:109-119, 1998.

FILS-LYCAON B. \& BURET M. Loss of firmness and changes in pectic fractions during ripening and overripening of sweet cherry. HortScience, 25:777-778, 1990.

FISCHER, M.; ARRIGONI, E. \& AMADO. Changes in the pectic substances of apples during development and postharvest ripening. Paert II: Analysis of the pectic fractions. Carbohydrate Polymers 25:167-175, 1994.

FRY, S. C. Oxidative scission of plant cell wall polysaccharides by ascorbate-induced hydroxyl radicals. Biochemical Journal, 332:507-515, 1998.

GALLEGO, P. P. \& ZARRA, I. Changes in cell wll composiiton and water-soluble polysaccharides during kiwifruit development. Annals of Botany, 79:695-701, 1997.

GIOVANNONI, J. J.; DELLAPENNA, D.; BENNETT, A. B. \& FISCHER, R. L. Expression of a chimeric polygalacturonase gene in transgenic rin (ripening inhibitor) tomato fruit results in polyuronide degradation but not fruit softening. The Plant Cell, 1: 5363, 1989. 
GOTO T.; GOTO M.; CHACHIN K. \& IWATA T. The mechanism of the increase of firmness in strawberry fruit treated with $100 \% \quad \mathrm{CO}_{2}$. Nippon Shokuhin Kagaku Kogaku Kaishi, 43: 1158-1162, 1996.

GROSS K.C. \& SAMS C.E. Changes in cell wall neutral sugar composition during fruit ripening: A species survey. Phytochemistry, 23: 2457-2461, 1984.

HADFIELD, K.A.; ROSE, J.K.C.; YAVER, D.S.; BERKA, R.M. \& BENNETT, A.B. Polygalacturonase gene expression in ripe melon fruit supports a role for polygalacturonase in ripening-associated pectin disassembly. Plant Physiology, 117: 363-373, 1998.

HAYAMA, H.; SHIMADA, T.; HAJI, T.; ITO, A.; KASHIMURA, Y. \& YOSHIOKA, $\mathrm{H}$. Molecular cloning of a ripening-related expansin cDNA in peach: evidence for no relationship between expansin accumulation and change in fruit firmness during storage. Journal of Plant Physiology, 157:567-573, 2000.

HUBER, D. J. \& LEE, J.H. Polygalacturonase activity in ripening pericarp tomato fruit determined using pericarp discs. Journal of Experimental Botany, 40:1331-1336, 1989.

HUBER, D. J. \& LEE, J.H. Uronic acid products release from enzymically active cell wall and its dependency on enzyme quantity and distribution. Plant Physiology, 87:592-597, 1988.

HUBER, D J. Acidified phenol alters tomato cell wall pectin solubility and calcium content. Phytochemistry, 30:2523-2527, 1991.

HUBER, D.J. \& O'DONOGHUE, E.M. Polyuronides in avocado (Persea americana) and tomato (Lycopersicon esculentum) fruits exhibit markedly different patterns of molecular weight downshifts during ripening. Plant Physiology, 102: 473-480,1993
HWANG, Y-S.; HUBER, D.J. \& ALBRIGO, G. Comparison of cell wall components in normal and disordered juice vesicles of grapefruit. Journal of the American Society for Horticultural Science, 115: 281-287, 1990.

JACKMAN, R. L.; GIBSON, H. J. \& STANLEY, D.W.. Effects of chilling on tomato fruit texture. Physiologia Plantarum, 86:600-608, 1982.

KANAZAWA, S.; SANO, S.; KOSHIBA, T. \& SHIMARU, T. Changes in antioxidative enzymes in cucumber cotyledons during natural senescence: Comparison with those during dark-induced senescence. Physiologia Plantarum, 109:211-216, 2000.

KERTESZ, Z. I. Pectic enzymes. II. Pectin enzymes of tomatoes. Food Research, 3:481$487,1938$.

KITAGAWA, Y.; KANAYAMA, Y. \& YAMAKI, $\mathrm{S}$. Isolation of beta-galactosidase fractions from Japanese pear: Activity against native cell wall polysaccharides. Physiologia Plantarum, 93:545-550, 1995.

KOVACS, E.; VANBUREN, J. P.; PITIFER, L. A.; HOCH, H. C. \& TERHUNE, B. T. Effect of irradiation and storage on cell wall structure of Golden Delicious and Empire apples. Acta Alimentaria, 26:171-190, 1997.

KRAMER M.; SANDERS, R.; BOLKAN, H.; WATERS, C.; SHEEHY, R. E. \& HIATT, W. R. Postharvest evaluation of transgenic tomatoes with reduced levels of polygalacturonase: processing, firmness and disease resistance. Postharvest Biology and Technology, 1: 241-255, 1992.

LI, S.; HAN, J-W.; CHEN, K-C. \& CHEN, C-S. Purification and characterization of isoforms of $\beta$-galactosidases in mung bean seedlings. Phytochemistry, 57:349-359, 2001. 
LOW, P.S. \& MERIDA, J.R. The oxidative burst in plant defense: Function and signal transduction. Physiologia Plantarum, 96:533542, 1996.

LURIE, S.; LEVIR, A.; GREVE, C. \& LABAVITCH, J. M. Pectic polymer changes in nectarines during normal and abnormal ripening. Phytochemistry, 36:11-17, 1994.

LYNCH, D.V. \& THOMPSON, J.E. Lipoxygenase-mediated production of superoxide anion in senescing plant tissue. Federation of European Biochemical Societies Letters, 173:251-254, 1984.

MCCARTNEY L.; ORMEROD, A.P.; GIDLEY, M.J. \& KNOX, J.P. Temporal and spatial regulation of pectic $(1 \rightarrow 4)-\beta$-D-galactan in cell walls of developing pea cotyledons: implications for mechanical properties. Plant Journal, 22:105-113, 2000.

MEDINA-ESCOBAR, N.; CARDENAS, J.; MOYANO, E.; CABALLERO, J.L. \& MUNOZ-BLANCO, J. Cloning, molecular characterization and expression of a strawberry ripening-specific cDNA with sequence homology to pectate lyase from higher plants. Plant Molecular Biology, 34:867-877, 1997.

MELOTTO, E.; GREVE, L. C. \& LABAVITCH, J. M. Cell wall metabolism in ripening fruit. VII. Biologically active pectin oligomers in ripening tomato (Lycopersicon esculentum Mill.) fruits. Plant Physiology, 106:575-581, 1994.

MILLER, A. R. Oxidation of cell wall polysaccharides by hydrogen peroxide: A potential mechanism for cell wall breakdown in plants. Biochemical and Biophysical Research Communications, 141:238-244, 1986.

MOORE, T. \& BENNETT, A.B. Tomato fruit polygalacturonase isozyme 1.Characterization of the $\beta$-subunit and its state of assembly in vivo. Plant Physiology, 106:1461-1469, 1994.
MORETTI, C.L.; SARGENT, S.A.; HUBER, D.J.; CALBO, A.G. \& PUSCHMAN, R. Chemical composition and physical properties of pericarp, locule, and placental tissues of tomatoes with internal bruising. Journal of the American Society for Horticultural Science, 123:656-660, 1998.

MORIGUCHI, T.; ABE, K.; TANAKA, K. \& SANADA, T. Polyuronides changes in Japanese and Chinese pear fruits during ripening on the tree. Journal of the Japanese Society of Horticultural Science, 67:375-377, 1998.

MUDA, P.; SEYMOUR, G. B.; ERRINGTON, N. \& TUCKER, G.A. Compositional changes in cell wall polymers during mango fruit ripening. Carbohydrate Polymers, 26:255-260, 1995.

NAIR A. R. \& SHOWALTER, A. M. Purification and characterization of a wound-inducible cell wall cationic peroxidase from carrot roots. Biochemical and Biophysical Research Communications, 226:254-260, 1996.

O'CONNOR-SHAW, R. E.; ROBERTS, R.; FORD, A.L. \& NOTTINGHAM, S.M. Shelf life of minimally processed honeydew, kiwifruit, papaya, pineapple and cantaloupe. Journal of Food Science, 59:1202-1206, 1215, 1994.

O'DONOGHUE, E. M.; SOMERFIELD, S. D.; SINCLAIR, B. K. \& KING, G. A. Characterization of the harvest-induced expression of $\beta$-galactosidase in Asparagus officinalis. Plant Physiology and Biochemistry, 36:721-729, 1998.

PATEL, D. S. \& PHAFF, H. J. Properties of purified tomato polygalacturonase. Food Research, 25:47-57, 1960.

PATHAK N,; MISHRA S.; SANWAL GG. Purification and characterization of polygalacturonase from banana fruits. Phytochemistry, 54: 147-152, 2000. 
PATHAK, N. \& SANWAL, G.G. Multiple forms of polygalacturonase from banana fruits. Phytochemistry, 48: 249-255, 1998.

PAULL, R. E. Ripening behavior of papaya (Carica papaya 1.) exposed to gamma irradiation. Postharvest Biology and Technology, 7:359-370, 1996.

PAULL, R.E.; GROSS, K. \& QIU, Y. Changes in papaya cell walls during fruit ripening. Postharvest Biology and Technology, 16:7989, 1999.

PRESSEY, R. Beta-galactosidases in ripening tomatoes. Plant Physiology, 71:132-135, 1983.

PRESSEY, R. Reevaluation of the changes in polygalacturonase in tomatoes during ripening. Planta,174:39-43, 1988.

PRESSEY, R. \& AVANTS, J.K. Two forms of polygalacturonase in tomatoes. Biochemica Biophysica Acta, 309: 363-369, 1973.

RANWALA, A.P.; SUEMATSU, C. \& MASUDA, $\mathrm{H}$. The role of $\beta$-galactosidases in the modification of cell wall components during muskmelon fruit ripening. Plant Physiology, 100:1318-1325, 1992.

REDGWELL, R. J.; MELTON, L. D. \& BRASCH, D. J. Cell wall dissolution in ripening kiwifruit (Actinidia deliciosa). Solubilization of the pectic polymers. Plant Physiology, 98:71-81, 1992.

REYMOND, D, \& PHAFF, H.J. Purification and certain properties of avocado polygalacturonase. Journal of Food Science, 30: 266-273, 1965.

RODRQGUEZ, R.; JIMINEZ, A.; GUILLIN, R.; HEREDIA, A. \& FERN ; NDEZ-BOLAYOS, J. Postharvest changes in white asparagus cell wall during refrigerated storage. Journal of Agricultural and Food Chemistry, 47:35513557, 1998.
ROSAHL, S. Lipoxygenases in plants - Their role in development and stress response. Zeitschrift für Naturforschung, 51:123-138, 1996.

ROSE, J. K. C.; HADFIELD, K.A.; LABAVITCH, J.M. \& BENNETT, A.B. Temporal sequence of cell wall disassembly in rapidly ripening melon fruit. Plant Physiology, 117: 345-361, 1998.

ROSE, J.K.C.; COSGROVE, D.J.; ALBERSHEIN, P.; DARVILL, A.G. \& BENNETT, A.B. 2000. Detection of expansin proteins and activity during tomato fruit ontogeny. Plant Physiology, 123:1583-1592, 2000.

ROSS, G S.; REDGWELL, R. J. \& MACRAE, E.A. Kiwifruit beta-galactosidase: Isolation and activity against specific fruit cell-wall polysaccharides. Planta, 189:499-506, 1993.

ROSS, G. S.; WEGRZYN, T.; MACRAE, E. \& REDGWELL, R. J. Apple $\beta$-galactosidase. Activity against cell wall polysaccharides and characterization of a related cDNA clone. Plant Physiology, 106:521-528, 1994.

RUSHING, J. W. \& HUBER, D. J. Effects of $\mathrm{NaCl}, \mathrm{pH}$ and $\mathrm{Ca}^{2+}$ on autolysis of isolated tomato fruit cell walls. Physiologia Plantarum, 70: 78-84, 1987.

SAKURAI, N. 1998. Dynamic function and regulation of apoplast in the plant body. Journal of Plant Research, 111:133-148, 1998.

SAKURAI, N. \& NEVINS, D.J. Relationship between fruit softening and wall polysaccharides in avocado (Persea americana Mill) mesocarp tissues. Plant and Cell Physiology, 38: 603-610, 1997.

SCHWEIKERT, C.; LISZKAY, A. \& SCHOPFER, P. Scission of polysaccharides by peroxidase-generated hydroxyl radicals. Phytochemistry, 53: 565-570, 2000. 
SEYMOUR, G. B.; LASSLETT, Y. \& TUCKER, G.A. Differential effects of pectolytic enzymes on tomato polyuronides in vivo and in vitro. Phytochemistry, 26:3137-3139, 1987.

SISLER, E.C. \& SEREK, M. Inhibitors of ethylene responses in plants at the receptor level - Recent developments. Physiologia Plantarum, 100:577-582, 1997.

SISLER, E.C. \& SEREK, M. Compounds controlling ethylene receptor. Botanical Bulletin of Academia Scinicia, 40:1-7, 1999.

SMITH, D.L. \& GROSS, K.C. A family of at least seven $\beta$-galactosidase genes is expressed during tomato fruit development. Plant Physiology, 123:1173-1183, 2000.

SMITH, C. J. S.; WATSON, C. F.; MORRIS, P. C.; BIRD, C. R.; SEYMOUR, G. B.; GRAY J.E.; ARNOLD, C.; TUCKER, G. A.; SCHUCH, W.; HARDING, S. \& GRIERSON, D. Inheritance and effect on ripening of antisense polygalacturonase genes in transgenic tomatoes. Plant Molecular Biology, 14: 369-379, 1990.

SODA, I.; HASEGAWA, T.; SUKUKI, T. \& OGURA, N. Changes of polyuronides in kiwifruit during ripening. Agricultural and Biological Chemistry 51:581-582, 1987.

SOZZI, G. O.; CASCONE, O. \& FRASCHINA, A. A. Effect of a high-temperature stress on endo$\beta$-mannanase and $\alpha$ - and $\beta$-galactosidase activities during tomato fruit ripening. Postharvest Biology and Technology, 9:4963, 1996.

TAKAHAMA, U. \& ONIKI, T. A peroxidase/phenolics/ascorbate system can scavenge hydrogen peroxide in plant cells. Physiologia Plantarum, 101:845-852, 1997.

THEMMEN, A.P.N.; TUCKER, G.A. \& GRIERSON, D. Degradation of isolated tomato cell walls by purified polygalacturonase in vitro. Plant Physiology, 69:122-124, 1982.
TUCKER, G.A.; SIMONS, H. \& ERRINGTON, N. Transgenic tomato technology: enzymic modification of tomato pastes. Biotechnology and Genetic Engineering Reviews, 16:293308, 1999.

UGALDE, T. D.; JERIE, P. H. \& CHALMERS, D. J. Intercellular $\mathrm{pH}$ of peach and apricot mesocarp. Australian Journal of Plant Physiology, 15: 505-517, 1988.

VANACKER, H.; HARBINSON, J.; RUISCH, J.; CARVER, T.L.W. \& FOYER, C.H. Antioxidant defences of the apoplast. Protoplasma, 205:129-140, 1998.

VON MOLLENDORFF, L. J.; DE VILLIERS, O. T.; JACOBS, G. \& WESTRAAD, I. Molecular charactersitics of pectic constituents in relation to firmness, extractable juice, and wooliness in nectarines. Journal of the American Society for Horticultural Science, 118:77-80, 1993.

WAKABAYASHI, K. Changes in cell wall polysaccharides during fruit ripening. Journal of Plant Research,113:231-237, 2000.

WAKABAYASHI, K.; CHUN, J-P. \& HUBER, D.J. Extensive solubilization and depolymerization of cell wall polysaccharides during avocado (Persea americana) ripening involves concerted action of polygalacturonase and pectinmethylesterase.

Physiologia

Plantarum, 108:345-352, 2000.

WAKABAYASHI, K. \& HUBER, D.J. Purification and catalytic properties of polygalacturonase isoforms from ripe avocado (Persea americana) fruit mesocarp. Physiologia Plantarum, (in press), 2001.

WATADA, A. E.; KO, N. P. \& MINOTT, D. A. Factors affecting quality of fresh-cut horticultural products. Postharvest Biology and Technology, 9:115-125, 1996.

WATADA, A. E. \& QI, L. Quality of fresh-cut produce. Postharvest Biology and Technolology, 15:201-205, 1999. 
WATSON, C.F.; ZHENG, L. \& DELLAPENNA, D. Reduction of tomato polygalacturonase beta subunit expression affects pectin solubilization and degradation during fruit ripening. The Plant Cell, 6:1623-1634, 1994.

SATO, Y.; SUGIYAMA, M.; TAKAGI, T. \& FUKUDA, H. Purification of cationic peroxidases bound ionically to the cell walls from the roots of Zinnia elegans. Journal of Plant Research, 108:463-468, 1995.
YU, L.; REITMEIER, C. A. \& LOVE, M. H. Strawberry texture and pectin content as affected by electron beam irradiation. Journal of Food Science, 61:844-846, 1996.

ZARRA, I.; SANCHEZ, M.; QUEIJEIRO, E.; PENA, M.J. \& REVILLA, G. The cell wall stiffening mechanism in Pinus pinaster Aiton: regulation by apoplastic levels of ascorbate and hydrogen peroxide. Journal of the Science of Food and Agriculture, 79:416-420, 1999. 